\title{
The Mongol Invasion of Kashmir
}

\section{Sameer Ahmad Sofi*}

\begin{abstract}
Medieval period of Kashmir history is the most neglected part of Indian History. This paper is an attempt to remove the confusion, with the support of the original contemporary sources, regarding Mongol invasion of Kashmir. Study discloses that due to invasions of Mongols as local armies could not put up resistance, Kashmir suffered immensely. It took years to recover politically and economically.
\end{abstract}

Key words: Baramulla ,Zulaji, Suhadeva,

*Aligarh Muslim University, India 
The middle ages of Kashmir begin with the Mongol invasion of 1320. The Mongols invaded the valley by coming through western/Baramulla pass in 1320. Kashmir at that time was ruled by Suhadeva [1301-1320]. He was very unpopular among his subjects because of the heavy fines and taxes which he exacted from them ${ }^{1}$. Suhadeva like his predecessors neglected the defence of the country by leaving the passes unguarded. As a result, adventurers and spies entered the valley without any difficulty2. Socially and morally the people of Kashmir had sunk to the lowest depths, for young and old had taken to falsehood, intrigue, dishonesty and discord. Such was the state of affairs when the storm of foreign invasion burst upon the country by Zulju ${ }^{3}$. Jonaraja says Zulju was the commander of the great king Karmasena and calls him by the name Zalacha or Zalcha or Duluch4. The author of Baharistanshahi calls him Zuluchu and Mirza Haider Daughlat calls him Zulaji5. However there is discrepancy among the historian regarding his identity. Abul Fazl, who based himself entirely on the Sanskrit chronicles for this period of Kashmir History refers to Zulju as the chief Commander of the king of Qandhar which is contrary to Jonaraja. Nizamuddin Ahmad and Ferishta also held that he was the mir-bakshi of the ruler of Qandhar6. But these views cannot be accepted, because Qandhar did not have at that time any chief of its own but was a possession of Ghiyasuddin, the Kurt ruler of Herat, who was tributary to the Il-Khans of Persia7. Ghiyasuddin himself was not powerful enough to send an army for the conquest of Kashmir and besides he was confronted with internal rebellions and intrigues and with an invasion of Prince Yasur, the Nikudari ${ }^{8}$. It is therefore wrong to say that Zulju came from Qandhar. Zulju was in reality a Mongol who came from Turkistan ${ }^{9}$, as said by Haider Malik, that he came from Turkistan which was at that time ruled by descendents of Chaghatay, the son of Changez Khan ${ }^{10}$ and his army

\footnotetext{
1 Jonaraja, Rajtarangni, Eng. Tr. J.C.Dutt,1991 Kings of Kashmira, ,Firma KLM, Cacutta, $p .9-14$

2 Ibid.,p.17

3 Haider Malik, Tarikh-I-Kashmir,MS. RPD, Srinagar, ff, 93b-94b.

4 Persian Chroniclers call him Zulju,Jonaraja[Cal.Ed.] calls him Zalacha or Zalcha, Jonaraja [Bo.Ed;No.152] calls him Duluch, Narain koul and Azam had Islamised his name as Zuqadar Khan.

5 Baharistanshahi,op.cit. p.17.

Abul Fazl, Ain-i-Akberi,ii.p.381.

Nizamuddin Ahmed, Tabakat-i-Akberi,iii,Munich MS,f 47a.

Khwand Amir, iii, part ii, p.69, Saif.B.Mohammad, Tarikh-Nama-I-Heart, pp. 369 Sqq.

Howorth, History of Mongols,iii.pp. 568-69. 590-91see also Saif.B.Mohammad, Tarikh-Nama-I-Heart, pp.680 Sqq

10 H. Malik, Tarikh-i-Kashmir,95b, Hassan.B.Ali, Tarikh-i-Hassan, 91a.
} 
consisted of both Turks and Mongols ${ }^{11}$. As regards his religion, he does not seem to be a muslim because at this time only a few Chaghtay chiefs had embraced Islam. Most of them had remained attached to the Pagan beliefs of their forefathers ${ }^{12}$.

In the $13^{\text {th }}$ century, the Mongols from the Mongolian Steppes, overran considerable parts of Asia and Europe. Kashmir too was subjected to a series of invasions. Thus Ogatay, Changez Khan's third son dispatched Mugatu towards India and Kashmir and he returned after ravaging parts of these countries $^{13}$. Again in 1253, Tair was sent with an army to Kashmir and India ${ }^{14}$. After Tair's death his troops came under the command of Sali who is said to have conquered Kashmir and sent several thousand prisoners to Halagu Khan ${ }^{15}$. Details regarding the nature of these Mongol invasions are not available, but they have affected only outer fringes of Kashmir. The invasion of Zulju was the continuation of these inroads to conquer the valley.

Zulju's invasion of Kashmir took place during the reign of Suhadeva. However, there is no unanimous opinion among the historians and sources of Kashmir history regarding its date. Haider Malik and Baharistanshahi are incorrect about the date of Dalucha's invasion. They dated it 1323, where as Jonaraja dated it 1320 which is correct as corroborated by the other sources also.

Zuluja entered Kashmir via Jehlum Valley route, which connects Kashmir through north via Baramulla pass. He headed seventy thousand Mongolian and Turkish horsemen and foot soldiers. As the passes were not properly defended he did not met any resistance ${ }^{16}$.About the course of Zulju's invasion, Baharistanshahi gives us the details.

"Zulju ordered his soldiers to carry out a wholesale massacre of the natives. Whosoever fell into the hands between the boundaries of Kamraj and the extreme end of Maraj was put to the sword. People who

\footnotetext{
Prawdin, The Mongol Empire, pp.404-405.

Baharistanshahi, f,10 a. Jonaraja (Bo.Ed.), No.170. says Zulju's army consisted of Turks, Tajiks and Mlecchas.

13 Prawdin, The Mongol Empire, pp.141 Sqq; Vanbery, Bukhara, pp.406-07; also p 157, were the names of Chaghtay rulers of Transoxiana are given.

14 Minhaj, Tabakat-i-Nasiri(trans. Raverty) p.1126 n.6.

15 Ibid,1135 n.5, Howorth, History of Mongols,iii,184.

16 Tabakat-i-Nasiri (tr.Raverty),1191 n; Howorth, History of Mongols,iii,p.185; M.Hassan, Kashmir Under The Sultans, p.52.
} 
had run away into the forests and Mountains were captured. Men were killed, women and children were made prisoners and sold to the merchants and traders of Cathay who had accompanied his troops. All the buildings of the city and the villages were burnt. The invading army consumed as much of food grains as they needed and whatever remained they destroyed. The whole of Kashmir was subjected to destruction by their ungodly acts"17

The authorities of Kashmir offered no resistance to the Mongols either at the entry point, Baramulla pass or in the Valley. Suhadeva, as Jonaraja stated, have attempted to bribe the invader by paying a large sum of money, which he raised by taxing all classes of people including the Brahmanas, but the effect of this was that it increased the unpopularity of Suhadeva among his subjects and only served to Whet Zulju's appetite for loot. The Mongol chief instead of withdrawing continued to advance. Later on Suhadeva tried to organize resistance but did not succeed ${ }^{18}$. Suhadeva was much disheartened and discouraged by the tyranny of Zulju. He therefore fled to Kishtawar along with his close associates, leaving his subjects to the mercy of invaders who perpetrated all kinds of atrocities upon them ${ }^{19}$. Suhadeva's Commander, Ram Chand shut himself up in the fort of Gagangir in the pargana of Lar. Lar was the only place which remained partially safe from the furry of the Mongols ${ }^{20}$. Dalucha's troops went on killing people and looting their possessions. Nobody dared to come out of their hiding places in forests and mountains ${ }^{21}$. Ramchandra was the only person who tried to maintain some semblance of authority in the valley and after Zulju's departure, he moved to Andarkot and drove out the Gaddi's who had come from Kishtawar on a raid 22 .

Baharistanshahi, f.2, P.17.

Jonaraja, ed. S.K.Koul, Vishveshvarandand institute, Hosiarpur, p.17.

Hassan.B.Ali, Tarikh-i-Hassan, 92b; Haider Malik, Tarikh-i-Kashmir, 96a-b;

Baharistanshahi, 12a.

20 Ibid, The District known as Lar comprises the whole of the territory drained by the Sindh and its tributaries. The Sanskrit chronicles call it Lhara (Jonaraja.180), but the Persian Chronicles call it Lar. The fort of Lar is situated in the valley of Gagangir, see ( Aba RAfiuddin Ahmed's Nawadirul Akhbar, f.14a; Mohammad Azam's Wakiat-i-Kashmir,f.11a; Pir Hassan Shah's Tarikh-i-Hassan,ii,82a).

Baharistanshahi, op.cit,p.17.

M.Hassan, Kashmir Under The Sultans, Gulshan Publishers Kashmir, 2002, P.52. 
Taking advantage of the prevailing confusion, Rinchana also fished in the troubled waters. He came forth from the place of his residence in the Lar valley and plundered the neighboring localities. In the words of Jonaraja," Dalucha and Rinchana blockaded the town (of Srinagar) in the East and in the north(respectively)", and the people first fled towards the west and then in the direction of Yama(South). Dalucha was like a blow in the water and on the Hill, Rinchana was like a tempest, while the chief man in the town, the prosperous and the rich, were struck with fear, as the kite swoops on the young ones of the bird thrown out of their nests, so the army of Rinchana seized the people of Kashmir ${ }^{23}$.

The Mongols continued their ravages in the valley for about eight months, until the commencement of the winter. The people of Kashmir were reduced to such a state of helplessness that they could not attend the work of tilling their land. The inhabitants had either been killed or escaped to the mountains as the Mongols had consumed or burnt the existing stocks of grain in the country. They were now threatened by an acute shortage of supplies. It was also due to this reason that Dalucha decided to depart from the valley ${ }^{24}$. They deliberated over the question of the route they should follow to come out of Kashmir. His officers advised him to leave from the same route of Baramulla and Pakhli by which he had entered, because it was shorter and passable even in winter. But he ignored their advice and enquired from the prisoners. The detained people of kashmir, took revenge on the Mongols for their sufferings by directing them to most hazardous route via Tarbal/Birnal ${ }^{25}$. On reaching the top of the mountain in Devsar Pargana, God's wrath hurled upon them rain of destruction. Thunderbolts were let loose. Such was the onslaught of rain and snow that all the soldiers, the Turks and the Prisoners met with their death and nobody survived. Tarikh-i-Malik Haider says that 5000 captives perished in the disaster ${ }^{26}$.

Giving a graphic description of Dalucha's invasion, G.M.D.Sufi says," He came, plundered, killed, seized and departed". According to Pandit Birbal Kachru,"

Jonaraja, op.cit, pp.17-18.

Baharistanshahi,op.cit, pp.17-18.

Name of The pass in the mountaneous area of Devsar pargana (see Jonaraja, p.69), the route over it lead to the Vitasta(Srivara,I,7. 206-07), identified with Bichlari river valley by Stein (see Rajtarangni,vol.iii,177 n.) one more possible reading of this word can be Barbal (see Rajtarangni,vol.ii, p.399).

26 Tarikh-i-Malik Haider,MS, RPD, Acc. No.39,f 56 and Tarikh-i-Nirayan Koul,MS,RPD, Acc. No. 934, cat.f 40b. 
Dalucha's invasion in Kashmir resembled the bloody orgies of Chingez and Halagu $^{27}$.

Kashmir was thus survived from the ravages of Turks and Dulucha. The surviving Kashmiris who had been hiding themselves in the mountains to escape massacre or the enslavement of invading army, came out of their hiding places and went to their former abodes and dwelling places in the hope of finding survivors among relatives or kinsmen. They found that the domain of Kashmir had been totally destroyed. Jonaraja describes the ravages tellingly, 'Depopulated, uncultivated, grainless and gramineous, the country of Kashmir offered as it were, the sight of primal chaos." Hassan Kiohami says that,"out of hundred persons only one survived and the city of Srinagar shrank to only eleven families ${ }^{28}$. They could not found their houses, friends or relatives and such sadness, fear and gloom overpowered their hearts that they preferred death to life. For many years after Mongol wrath, the lands in Kashmir remained uncultivated and unproductive. Even after three centuries elapsed, if a piece of land lies uncultivated, people used to say that Dulucha must have passed the way ${ }^{29}$.

Finding that Kashmir was in a state of desolation, the depredators and robbers living in the mountains poured into it from all sides. They began to attack the Kashmiris in their distress and seized their womenfolk and children as captives. The robbers belonged to the tribes of Khasas or Khakhas. Jonaraja describes them as Abhisaras who lived between Vitasta and Chandrabhaga (Jehlum and Chinab rivers) ${ }^{30}$. Under these circumstances in every Pargana, forty or fifty villages combined to accept one man as their chief and collected all possible military equipments to protect their families and property 31 .

As there was no organized government in the country, the local chiefs made themselves independent. In some passes, the inhabitants themselves organized their defence against the depredations of robbers and the hill

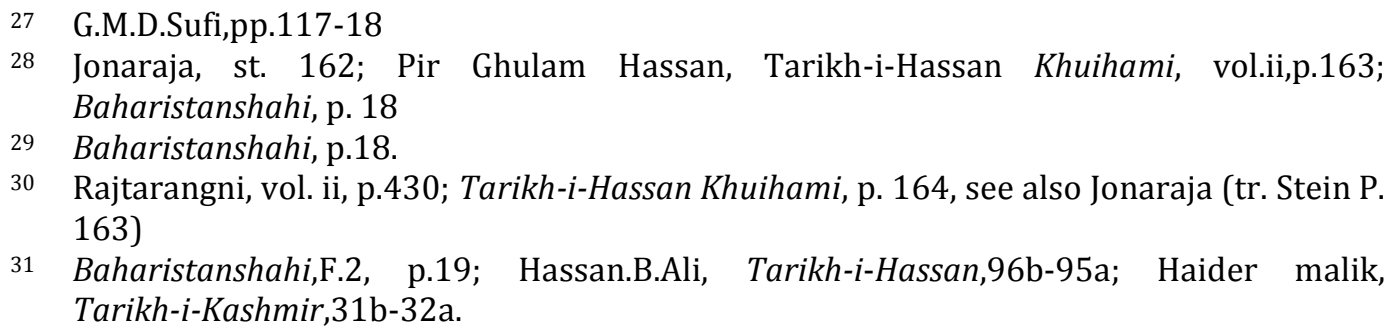


tribes by taking possession of a fort and some strong persons were posted as the kotwals of these forts. These Kotwals claimed independence and were not prepared to obey each other ${ }^{32}$. Among those who took advantage of the prevailing anarchy, the most prominent person was Rinchana. Such a condition of country presented a golden opportunity to anyone who had the will and strength to establish his authority and Rinchana had these in abundance. He had already obtained plentiful wealth by plundering the helpless Kashmiris during Dalucha's invasion ${ }^{33}$. His only rival was Ramchandra, who is said to have proclaimed himself as ruler. Hassan Khuihami in his Tarikh-i-Hassan says that, Rinchana was provided soldiers by Ramchand, who had proclaimed himself king to suppress the Khasas. After Suhadeva's fight, Rinchana was able to bring about Ramchandra's murder by a stratagem and his son and other family members were made prisoners. Thereafter Rinchan proclaimed himself as ruler ${ }^{34}$, who collected his forces in the Pargana of Lar35.

During the reign of Udayanadeva [1323-39], Kashmir was once again invaded by the Mongols under a leader locally mentioned as Achala, he was a Turk. According to Jonaraja, Achala was supplied with soldiers by the lord of Mughdapur(Mughalpur)and forcibly entered Kashmir like another Dulacha ${ }^{36}$. The Persian chronicles call him 'Urwan', a Turk who entered Kashmir via Hirapur. We are tempted to identify Mughdapur of Jonaraja with Mughalpur. It is likely that the invader was some Turko-Mongol soldier of fortune who appears to have employed on this errand by some mohammedan chief of Punjab or Delhi. We are also told that Sultan Muhammad Bin-Tughlaq (1324-39) has also commissioned the famous khalifa, Maulana Shamsuddin of Delhi, to go to Kashmir and convert her idolaters to islam ${ }^{37}$. Udayanadeva fled towards Ladakh at the first sight of the enemy, Achala, leaving his Queen, Kota Rani, to face the situation alone. Luckily, Kota Rani proved equal to the occasion. She joined hands with Shahmir and appealed to all the Rajas for assistance and they drove the invader out and the Queen recalled Udayanadeva.

Baharistanshahi,f.2, p.19. See also M.Hassan, Kashmir Under the Sultans,p.54.

Jonaraja, p.18.

M.L.Kapur, A History of Medieval Kashmir,pp.14-15.

Baharistanshahi,f.2, p.19.

Jonaraja,p.25.

Abul Haq, Akhbar-ul-Akhyar,p.97. 
Jhss, Vol. 7, No. 2 , July to December, 2016

Nodoubt, the Mongal invasion of Kashmir under Dalcha was short lived but it proved fatal blow for Hindu rule in Kashmir and became a torchbearer of Muslim ruler in Kashmir in 1339 under Shahmir. It had enormous repercussion and caused both human and material loss which took many years to recover. 


\section{References}

Abul Fazl, Ain-i-Akberi

Abul Haq, Akhbar-ul-Akhyar,

Baharistanshahi,

Haider Malik, Tarikh-i-Kashmir,

Haider Malik, Tarikh-I-Kashmir,MS. RPD, Srinagar,

Hassan.B.Ali, Tarikh-i-Hassan

Howorth, History of Mongols,

Jonaraja, ed. S.K.Koul, Vishveshvarandand institute, Hosiarpur,

Jonaraja, Rajtarangni, Eng. Tr. J.C.Dutt, Kings of Kashmira, ,Firma KLM, Cacutta,1991

M.Hassan, Kashmir under the Sultans

M.Hassan, Kashmir under the Sultans, Gulshan Publishers Kashmir, 2002

M.L.Kapur, A History of Medieval Kashmir,

Minhaj, Tabakat-i-Nasiri(trans. Raverty)

Nizamuddin Ahmed, Tabakat-i-Akberi, iii,Munich $\quad$ MS

Prawdin, The Mongol Empire, 
Jhss, Vol. 7, No. 2 , July to December, 2016

Rajtarangni, vol. ii

Saif.B.Mohammad, Tarikh-Nama-I-Heart,

Tarikh-i-Malik Haider,MS, RPD, 